International Journal of Engineering \& Technology, $7(3.15)(2018) 301-305$
International Journal of Engineering \& Technology
SPC
Website $:$ www.sciencepubco.com/index.php/IJET
Research paper

\title{
Adaptation of the Land Use System as One of the Main Paradigms of the Modern Agricultural Land Use
}

\author{
Yuri Mikhailovich Rogatnev ${ }^{1 *}$, Valentina Nikolaevna Scherba ${ }^{1}$, Tatyana Vladimirovna Marakaeva ${ }^{1}$, Tatyana \\ Viktorovna Nozhenko ${ }^{1}$, Natalia Alexandrovna Kapitulina ${ }^{1}$
}

${ }^{1}$ Omsk State Agrarian University under P.A. Stolypin, Institutskaya Square, 2, Omsk, 644008, Russia

*Corresponding author E-mail: rogatnev.yu.m@mail.ru

\begin{abstract}
The article reveals one of the main paradigms for the agricultural land use development. Adaptation is not only a necessity, but a means to improve sustainability and efficiency in the use of agricultural land. The conditions of external systems that determine the direction and magnitude of adaptation options for agricultural land use have also been shown. The features of adaptation of the basic land use elements have been described: land plots, legal status, engineering equipment of the territory, land use system, and land use maintenance system. The article provides a more detailed overview of the adaptation of the main land use system element (agriculture), which will ensure the adaptation of crops and their varieties to the features of soils and terrain; the adaptation of cultivation technologies to the soil and terrain, the features of the territory; the adaptation of fertilizer systems to soils and crops and their varieties; the adaptation of cultivation technologies to the actual technical equipment; the adaptation of the farming system to the actual financial condition; and the adaptation of the farming system to the natural conditions of the year. A monographic description of the land use adaptation experiment by Chistoe, LLC in the Tyukalinsky District of the Omsk Region has been produced. Mutual adaptation of both land management and its technical and technological components has been proposed for the agricultural land development project. It is expected that this will minimize the required financial costs by adapting land properties, reducing types of machines and the technologies used.
\end{abstract}

Keywords: Adaptation; Agricultural land use; Agriculture; Land management, Land properties; Land development

\section{Introduction}

Basically, two mechanisms are used in the social development system. The first one is associated with the uneven development, based on the reforms' implementation. They fundamentally change a large part of the modalities for the system functioning, its structure, and, most importantly, the targets. Actually, this happened with the agricultural land use system in implementing a modern agrarian reform. The land system of Russia, agrarian relations and basic land use parameters have changed. This took a decade. However, the reform cannot take place constantly, since it is associated with significant costs to society and creates an imbalance of key system components. The reform momentum fades, and further development is entering a continuous and gradual change. In fact, agricultural land use is now in this stage of development. It involves the adaptation of the land use organization to a new agrarian system, the conditions of the market economy and changing natural conditions. This is what ensures a high economic efficiency of land use, preservation, restoration and development of their productive capacity.

The second mechanism involves a gradual change in conditions and settings, improvement of both land use system and land relations. This mechanism is extremely important in the after-reform period and allows eliminating the reform shortcomings and forming a new land policy. With its implementation, it is extremely important to timely analyze the changes that occur and adopt the appropriate management decisions. This is a characteristic feature of the modern land use systems.

\section{Methods}

When studying the problems of adaptation of the land use system, their essence has been generated in the form of a system of interrelated and interdependent elements. It has been found that agricultural land use adaptation relies on the actual state of its settings and the processes that modify them. But the vector of adaptation is determined by the tasks of production, for which such land use is being improved. On this methodological basis, specific methods of adaptation have been monographically studied on the basis of Chistoye LLC.

\section{Results}

Land use (use of land) as a system has a fixed location (economic site with certain boundaries on the surface of the planet). It includes the following elements:

- land plots with certain natural properties (territory, relief, soil, vegetation, hydrography and hydrology);

- legal status of land plots;

- engineering equipment of the territory, providing the use of land (roads, production centers, engineering protection facilities of the territory, irrigation canals);

- the land use system (farming system, pasture system, land use restrictions and encumbrances); and

- the land use provision system (land management, land improvement, etc.) [1]. 
The land use system as an anthropogenic system based on the functioning of the land as a natural complex has a specific purpose and objectives of its existence and operation period. These are the tasks of the social development that generate different land use systems, which, therefore, arise, improve and disappear. Therefore, the land use system relies on the ecological, social and economic systems and must comply with them, thus ensuring its sustainability and efficiency. Therefore, all these supersystems forming the content of the land use system in relation to it are both internal factors and the most important external conditions. Therefore, the land use system should be adapted to these supersystems [2].

Adaptation (Lat. adapto) is the adaptation of the structure and functions of the system and the processes occurring in its framework to the external environment and internal processes. The adaptation processes are focused on maintaining the constancy of their internal state through coordinated reactions aimed at maintaining the dynamic balance of the system, reproducing itself, restoring the lost balance, and overcoming the resistance of the external environment [3].

All previously allocated elements of the land use system undergo adaptation processes. Land management as a set of measures to create and improve the territorial system of land use, to change and improve land properties, to regulate external processes that modify them to ensure the agricultural production processes plays the main role in the land use system adaptation.

Adaptation of spatial properties of the land use system consists in adapting the territory organization, both to the system of agricultural nature management and to the emerging agricultural production system. The minimum economic sites (working sites, fields, irrigation sites and pastures) should have uniform natural properties, which ensure uniformity of economic methods of use and a reduction in technological costs. Larger economic sites (crop rotation, pasture rotation areas, cutting rotation areas) should ensure the most effective application of their use schemes (crop rotation patterns, grazing time, and haymaking). All these sites should be suitable for cultivating certain crops and technologies for their cultivation. Adaptation is achieved by integrating the territorially distributed properties of the land into a single land use, ensuring the solution of the agricultural production tasks within its boundaries with the full, correct and effective use of land. The location of engineering facilities of the territory, which ensure the land use processes, adapt the quality of the land to solve production problems, ensure the protection of land from external impact, and also violate the created adaptation balances in the consumption of land properties, is inextricably linked with territorial adaptation. These adaptation-providing facilities include roads, irrigation and drainage canals, facilities of engineering protection of the territory.

In the agricultural land use system, the second important problem of adaptation is the adaptation of the land property use system (the farming system, pasture system, restrictions and encumbrances of land use) both to the land properties and to the production tasks. The farming system as an adaptation mechanism is a complex of technological (agrotechnical), meliorative and organizational measures for the use of land, restoration and improvement of soil fertility. The farming system includes a number of interrelated elements (methods of adaptation): the organization of crop rotations, the soil cultivation system, the fertilizer system, weed management, the management of diseases and pests of agricultural crops, seed production, measures to protect the soil from water and wind erosion; in some areas, irrigation, drainage, chemical reclamation (liming, gypsuming, etc.), and the creation of fieldprotective afforestation.

Adaptive farming is a fairly complex multipurpose task. It is designed to adapt all elements of the farming system to both the natural and resource features of agricultural land use and the production tasks and includes:

- adaptation of crops and their varieties to the characteristics of soils and terrain;

- adaptation of cultivation technology to soils, terrain, features of the territory;
- adaptation of the fertilizer system to soils and crops and their varieties;

- adaptation of technology of cultivation to actual technical equipment;

- adaptation of the farming system to the actual financial condition; and

- adaptation of the farming system to the natural conditions of the year [4].

Let us consider the analysis of the agricultural land use adaptation system based on Chistoye LLC of the Tyukalinsky District, Omsk Region, where the production of agricultural products is the main type of production activity [5]. The agricultural organization has a fairly extended land use organized on the basis of joint common ownership of land (Table 1). In this case, arable land accounts for $95 \%$ of all areas [6].

Table 1: The use of agricultural land in Chistoye LLC (as of 01.01.2017), ha

\begin{tabular}{cccc} 
Total & arable land & Including & \\
& hayfields & pastures \\
10,760 & 10,246 & 514 & - \\
\hline
\end{tabular}

However, the land use state of Chistoye LLC is far from favorable (Table 2). Almost all arable lands are saline to some extent, and the surrounding areas, including nonagricultural lands, have the signs of varying degrees of waterlogging.

Table 2: Quality condition and use of arable land in Chistoye LLC

\begin{tabular}{|c|c|c|c|c|}
\hline & \multicolumn{3}{|c|}{ Including, ha } & \multirow{3}{*}{$\begin{array}{l}\text { Quality score at- } \\
\text { tributed to land } \\
54\end{array}$} \\
\hline & waterlogged & saline & unused & \\
\hline 10,246 & - & 10,246 & - & \\
\hline
\end{tabular}

Therefore, arable plots have equal areas of medium and strong ecological tension (Table 3).

Table 3: Ecological state of the arable land in Chistoye LLC

\begin{tabular}{|c|c|c|c|c|}
\hline \multirow[t]{3}{*}{ Area, ha } & \multicolumn{4}{|c|}{ Ecological state } \\
\hline & \multicolumn{2}{|c|}{ average ecological tension } & \multicolumn{2}{|c|}{ strong ecological tension } \\
\hline & ha & $\%$ & ha & $\%$ \\
\hline 10,246 & $6,033.5$ & 58.9 & $4,212.5$ & 41.1 \\
\hline
\end{tabular}

This shows that the most serious problem of agricultural land use adaptation is the provision of agricultural production with arable land, which contributes to the effective crop production. The complex ecological state of the lands indicates the lack of suitability for agricultural use of the lands involved in arable rotation during clearing and those that do not provide for an effective crop production in the modern economic conditions [7]. The company has about $30 \%$ of such lands. Significant state subsidies are needed to ensure effective production. In addition, up to $25 \%$ of arable lands ensure the efficient production, which is unstable over the years. Therefore, the establishment of the composition and area of lands suitable for cultivating the main standard crops is the first task of adapting agricultural land use in Chistoye LLC. It leads to the need to reduce the area of arable land by 3-4 thous. ha. This will cause a reduction in the production and the need to dismiss part of the employees thereby increasing the burden of the state on the social security of the unemployed persons. In the case of significant government support, this reduction may be of a lesser extent. Adaptation, in this case, is a compromise between the need for efficient production and change in the land use direction and the escalation of costs for the state (or support to population or production).

Chistoye LLC cultivates grain crops and annual and perennial grasses (Table 4). The largest share of crops in the structure of the arable land use is reserved for grain crops $(41.0 \%)$ and perennial grasses $(33.6 \%)$, which does not fully correspond to the experience of practical farming and livestock farming as well as scientifically based structure of arable land use for organizations of the northern forest-steppe zone, according to which a specific weight of fallows is $14-16 \%$, grain crops $-52-58 \%$, grain legumes $-2-4 \%$, 
annual grasses - 8-10\%, perennial grasses - $10-12 \%$, and silage grasses $-10-12 \%[8]$.

Table 4: The specific weight of crops in the crop rotation at Chistoye LLC

\begin{tabular}{ccc}
\hline Crop & Area, ha & Specific weight, $\%$ \\
\hline Fallow & 2,155 & 21.0 \\
Annual grasses & 461 & 4.5 \\
Grain crops & 4205 & 41.0 \\
Perennial grasses & 3,425 & 33.6 \\
Total area & 10,246 & 100 \\
\hline
\end{tabular}

When analyzing the data on the structure of sown areas at Chistoye LLC, it should be noted that it does not fully correspond to the grain specialization. There are opportunities for its improvement and optimization in accordance with the production orientation of the company. Therefore, in order to adapt to the production objectives, it is recommended to increase the area for these crops by reducing the areas for fallows and perennial grasses The crop rotation system existing in Chistoye LLC confirms the wrong ratio and alternation of crops, since the fallowing and cultivation of perennial grasses is used in one crop rotation. It should also be noted that medium-stable (wheat, oats), unstable (peas) and stable (rindless barley, barley) crops are sown in the organization with respect to the culture salinization process [9]. In addition, crops such as barley are nonresistant to strong overmoistening on lands, and wheat, oats, peas, perennial grasses (smooth brome) are medium-resistant [10]. Therefore, for more strong adaptation to soil conditions, medium-demanding crops should be replaced with resistant and low-demanding ones, which will not affect the value and nutritiousness of these crops in ensuring high yields (Table 5).

Table 5: Recommended crop rotations for Chistoye LLC

\begin{tabular}{|c|c|c|}
\hline $\begin{array}{l}\text { Crop rotation } \\
\text { type }\end{array}$ & Area, ha & Crops rotation scheme \\
\hline \multirow{5}{*}{ Feeding } & $1,109.9$ & $\begin{array}{l}\text { Clover- clover - barley - oats - barley } \\
\text { with the sowing of sweet clover }\end{array}$ \\
\hline & 913.7 & $\begin{array}{c}\text { Annual grasses - barley - sunflower for } \\
\text { silage - oats }\end{array}$ \\
\hline & 1857.5 & $\begin{array}{l}\text { Sunflower for silage - wheat - wheat } \\
\text { with the sowing of perennial grasses - } \\
\text { perennial grasses } 1 \text { year - perennial } \\
\text { grasses } 2 \text { years - perennial grasses } 3\end{array}$ \\
\hline & & years - perennial grasses 4 years - oats \\
\hline & $1,936.0$ & $\begin{array}{l}\text { Seeded fallow - wheat - wheat with the } \\
\text { sowing of perennial grasses - perennial } \\
\text { grasses } 1 \text { year - perennial grasses } 2 \\
\text { years - perennial grasses } 3 \text { years - per- } \\
\text { ennial grasses } 4 \text { years - wheat }\end{array}$ \\
\hline \multirow{3}{*}{ Field } & $1,374.5$ & $\begin{array}{l}\text { Annual grasses - wheat - wheat - corn } \\
\text { for silage - wheat - oats }\end{array}$ \\
\hline & $1,332.0$ & $\begin{array}{c}\text { Seeded fallow - wheat- peas - wheat - } \\
\text { oats }\end{array}$ \\
\hline & $1,025.0$ & Seeded fallow - wheat- wheat- oats \\
\hline
\end{tabular}

The company territory is part of the Priyomsky geomorphological region - Neogene-lacustrine-alluvial plain, which is characterized by strong bogging and considerable salinity. The territory is represented by a significant number of small contours of lands caused by the flat nature of the surface with a significant manifestation of patelloid depressions. Therefore, the use of powerful highperformance equipment (sowing and harvesting units) is not efficient. To a large extent, it is impossible to adapt the spatial condition to the requirements for the development of technical means in the district. On the contrary, the brands shall be selected that ensure their effective use in the context of considerable elevation pattern of arable land, where each pattern serves as a separate economic area. The shortcomings of the spatial distribution of arable land could be compensated by developing a good quality field road network.

In the conditions of the predominance of meadow-chernozem, soloniform chernozem soils in the croplands of Chistoye LLC, mineral, organic fertilizers and gypsum are the main factors in the formation of high and stable crop yields. In general, in the arable land of Chistoye LLC, the humus balance is negative (-0.81 t/ha). The value of the efficiency index of the humus balance is 0.71 , which corresponds to the high intensity of the arable land use as a natural resource in the given agricultural organization. Deficiency of humus is $53.6 \%$, therefore, a large amount of manure (80,943.4 tons) is needed to replenish it. The use of organic and mineral fertilizers is one of the important measures aimed at increasing soil fertility and yield of crops. According to Yu. I. Ermokhin, due to the use of organic and mineral fertilizers, it is possible to obtain an increase of up to $26 \%$ in the productivity of arable land, and $33 \%$ - of fodder land [8].

Meadow soils develop when they are close to the groundwater surface. Therefore, it is advisable to use them for good-quality hayfields and pastures.

Solonetzes (alkali soils) are formed mainly during the desalinization of solonchaks (saline soils). Cultivation of agricultural crops is possible only with considerable ameliorative influence and, for the most part, as hayfields and pastures.

Saline soils are part of a group of saline soils with more than $1 \%$ of water-soluble salts in a surface layer, which is usually associated with shallow mineralized groundwater. Solod soils develop mainly in desalinization and dealkalinization of solonetzes under the conditions of increased surface moisture. They occur in flat, closed "wet" depressions among the forest-steppe soils. The upper horizons have an acidic reaction. All measures to improve these types of soils are agronomically, ecologically and economically profitable only with the considerable financial support from the state.

Marsh soils are excessively moistened throughout the year [11].

In the Tyukalinsky district, there are silty-marsh soils (the horizon of silt-the mineral mass mixed with the decomposed organic matter is replaced by gleic mineral one) and meadow-marshy ones (the upper mineralized, gleic horizon is replaced by mineral gleic one). Since these varieties of marsh soils are unsuitable for agriculture, they are recommended to be attributed to the land reclamation fund only after intensive drainage reclamation [12]. To adapt the soils for using them under arable land, it is necessary to do the following:

1. Minimize the treatment of soils by combining soil treatment methods in one pass.

2. To introduce organic-mineral fertilizers (nitrogen - in the spring, phosphorus - in the autumn).

3 . To partly replace clean fallows in crop rotations with seeded ones, since in the areas of sufficient moisture (the northern foreststeppe of the Omsk region) the economic efficiency of clean fallows is lower than that of the seeded ones (clover, vetch and oat, green manure, etc.). For example, with the same yield of winter crops for a clean and seeded fallow the production of a fallowgrown crop is additionally obtained from the seeded fallow. In addition, burying the remains of steam-absorbing crops into the soil increases its fertility.

4. Due to a large area of saline and waterlogged soils in the territory of the region, it is necessary to introduce crops resistant to these negative processes (sweet clover, alfalfa) into crop rotations.

Fodderlands (pastures and hayfields) located on meadow soils can also be improved by a number of measures:

1. Creation of herb cover.

2. Superficial improvement by disking.

3. Additional sowing of several types of grasses.

4. Seeding of grasses resistant to salinity [11].

It is better to place hayfields and pastures of natural origin on the meadow-marsh humus soil since this will allow obtaining an additional yield of fodder crops.

The middle solonetz can also be used in agriculture for cultural hayfields and medium-quality pastures. But for their maintenance and partial improvement, it is necessary in the middle of the life cycle of fodder crops to peel, and then to perform a deep loosening with subsequent rejuvenation with adapted grasses (brome, alfalfa). 
On strongly saline and heavily bogged soils (meadow-marshy silty, marsh and lowland and turfy, meadow solonchak, shallow, crusted, solodized), it is recommended to perform the conservation of land because they are not suitable for agriculture today (Table 6).

Table 6: Set of land improvement measures

\begin{tabular}{|c|c|c|c|}
\hline $\begin{array}{l}\text { Agricultural } \\
\text { group number }\end{array}$ & Soil name & $\begin{array}{l}\text { Share in the } \\
\text { total area of } \\
\text { arable } \\
\text { land, } \%\end{array}$ & $\begin{array}{l}\text { Improvement } \\
\text { measures }\end{array}$ \\
\hline II & $\begin{array}{c}\text { Meadow- } \\
\text { chernozem } \\
\text { solonetzic low- } \\
\text { power medium- } \\
\text { humus }\end{array}$ & 5.5 & $\begin{array}{l}\text { 1. Minimization of } \\
\text { the treatment of soils } \\
\text { by combining soil }\end{array}$ \\
\hline \multirow{3}{*}{ IV } & $\begin{array}{l}\text { Meadow- } \\
\text { chernozem } \\
\text { solonchakous, } \\
\text { low-power and } \\
\text { medium-power, } \\
\text { medium-humus }\end{array}$ & 11.6 & $\begin{array}{l}\text { treatment methods in } \\
\text { one pass. } \\
\text { 2. The introduction } \\
\text { of organomineral } \\
\text { fertilizers (nitrogen - } \\
\text { in spring, phospho- }\end{array}$ \\
\hline & $\begin{array}{l}\text { Chernozem- } \\
\text { meadow solo- }\end{array}$ & & $\begin{array}{l}\text { 3. The use of seeded } \\
\text { fallows }\end{array}$ \\
\hline & $\begin{array}{l}\text { netsous, solon- } \\
\text { chakous, low- } \\
\text { power and } \\
\text { medium-power, } \\
\text { low-humus and } \\
\text { medium-humus }\end{array}$ & 17.6 & $\begin{array}{l}\text { 4. Introduction of } \\
\text { salt-proof crops } \\
\text { (sweet clover, alfal- } \\
\text { fa) into the rotation }\end{array}$ \\
\hline \multirow{3}{*}{ VI } & $\begin{array}{l}\text { Meadow, low- } \\
\text { power and } \\
\text { medium-power, } \\
\text { low-humus and } \\
\text { medium-humus }\end{array}$ & 4.4 & $\begin{array}{l}\text { 1. Creation of herb } \\
\text { cover. } \\
\text { 2. Superficial im- } \\
\text { provement by disk- }\end{array}$ \\
\hline & $\begin{array}{l}\text { Meadow, sol- } \\
\text { onchakous, }\end{array}$ & & $\begin{array}{l}\text { 1ng. } \\
\text { of several types of }\end{array}$ \\
\hline & $\begin{array}{l}\text { low-power and } \\
\text { medium-power, } \\
\text { low-humus and } \\
\text { medium-humus }\end{array}$ & 6.9 & $\begin{array}{l}\text { grasses. } \\
\text { 4. Seeding of grasses } \\
\text { resistant to salinity }\end{array}$ \\
\hline \multirow[b]{2}{*}{ VII } & $\begin{array}{c}\text { Meadow-marsh } \\
\text { humus }\end{array}$ & 4.3 & $\begin{array}{l}\text { Natural hayfields } \\
\text { and pastures }\end{array}$ \\
\hline & $\begin{array}{l}\text { Medium solo- } \\
\text { netz }\end{array}$ & 7.4 & $\begin{array}{l}\text { In the middle of the } \\
\text { life cycle of culture, } \\
\text { peeling, then deep } \\
\text { loosening with sub- } \\
\text { sequent rejuvenation } \\
\text { with adapted herbs } \\
\text { (brome, alfalfa) }\end{array}$ \\
\hline \multirow[b]{2}{*}{ IX } & $\begin{array}{l}\text { Meadow-marsh } \\
\text { muddy }\end{array}$ & 5.8 & \multirow[b]{2}{*}{ Conservation } \\
\hline & $\begin{array}{l}\text { March lowland } \\
\text { and humus } \\
\text { Meadow sol- } \\
\text { onchak, small, } \\
\text { crusted, solodic }\end{array}$ & 9.7 & \\
\hline
\end{tabular}

Adaptation of agricultural land use should be an orderly, environmentally and economically effective measure. It is best to organize adaptation on the basis of land management. This allows linking all the directions of adaptation into a single whole, in which there will be no contradiction among the individual elements of the land use system. This is especially important in the context of a significant diversity of land and especially the properties of arable land. It is necessary to conduct information, technical and technological training to develop adaptation measures. Information preparation is provided by the land management, which provides information on the properties of land resources (organization of the territory, relief, soils, hydrography and hydrology, the bonitet score, the cost of individual plots, the effectiveness of cultivating specific crops on individual arable plots, legal status, placement of crop rotations, etc.). At the same time, GIS technologies should be used as an information support system for adaptation (electronic maps of different content). Technical and technological training is carried out by an economic entity acquiring or upgrading technical facilities and the necessary material resources for the implementation of adapted technologies. At the same time, it is necessary to envisage mutual adaptation both of land management and its technical and technological component. This will minimize the required financial costs by adapting land properties, reducing types of machines and the technologies used. Therefore, it is advisable to develop a kind of land development project, in which technological, technical and financial measures must exist along with land management ones. This project should be:

- environmentally effective to ensure (natural and anthropogenic) restoration of lost soil properties before the beginning of the next field recovery period for different technologies and crops the force of recovery action;

- cost-effective in which not only the cost recovery of all adaptation measures implementation is ensured, but also the adequate efficiency of agricultural production.

\section{Conclusion}

The concerns and suggestions on the adaptation of agricultural land use to the production system in various natural and economic conditions considered in the present work allow to develop a new approach for sustainable and effective agricultural production. The content and mechanism of the integrated adaptation form an environmentally sustainable and cost-effective system of agricultural land use organization. This is especially important in the context of the increasing instability of natural conditions and crisis phenomena in the economy.

\section{References}

[1] Rogatnev YuM, Scherba VN \& Nozhenko TV (2016), Innovatsionnyye metody issledovaniya $v$ zemleustroystve $i$ kadastrakh [Innovative methods of research in land management and cadastres] Omsk: FGBOU HE Omskiy GAU.

[2] Rogatnev YuM (2013), Zemel'nyye resursy kak resursnaya osnova innovatsionnogo razvitiya APK [Land resources as a resource basis for innovative development of the agroindustrial complex]. Bulletin of the Altai State Agrarian University 2(10), 14-18.

[3] Gushchin AI (2001), O prisposoblenii k osobennostyam prirodnykh usloviy $v$ adaptivno-landshaftnom zemledelii dlya povysheniya effektivnosti sel'skokhozyaystvennogo proizvodstva i obespecheniya ekologicheskoy bezopasnosti prirodnoy sredy [About adaptation to features of natural conditions in adaptive-landscape agriculture for increasing efficiency of agricultural production and maintenance of ecological safety of an environment]. Povysheniye ustoychivosti zemledeliya $\mathrm{v}$ sovremennykh usloviyakh [Increasing the sustainability of agriculture in modern conditions] materials of scientificpractical. conf. Administration of the Kirov region. Committee of Agriculture and Food. Kirov, 69-73.

[4] Beketov AD, Edimeichev YuF \& Beketova OA, Istoriya i metodologiya adaptivno-landshaftnykh i al'ternativnykh sistem zemledeliya [History and methodology of adaptive-landscape and alternative systems of agriculture]. Krasnoyarsk: b.i., 2012.

[5] Marakayeva TV \& Shcherba VN (2016), Analiz faktorov proizvodstva i puti povysheniya effektivnosti ispol'zovaniya zemel' sel'skokhozyaystvennymi organizatsiyami v Tyukalinskom rayone Omskoy oblasti [Analysis of production factors and ways to increase the efficiency of land use by agricultural organizations in the Tyukalinsky District of the Omsk Region]. Bulletin of the Altai State Agrarian University 5(139), 175-179.

[6] Nozhenko TV \& Marakayeva TV (2018), Analiz ispol'zovaniya zemel' sel'skokhozyaystvennogo naznacheniya Tyukalinskogo rayona Omskoy oblasti i perspektivy ikh razvitiya [Analysis of the use of agricultural land in the Tyukalinsky District of the Omsk Region and the prospects for their development]. In the collection: Nauchnyye innovatsii - agrarnomu proizvodstvu Scientific Innovations for Agricultural Production]. Materials Intern. scientific and practical conference dedicated to the 100th anniversary of Omsk State University. Omsk, 314-319.

[7] Kiryushin VI \& Ivanova AL (2005), Agroekologicheskaya otsenka zemel', proyektirovaniye adaptivno-landshaftnykh sistem zemledeliya $i$ agrotekhnologiy [Agro-ecological assessment of lands, design 
of adaptive-landscape systems of agriculture and agro-technologies]. Moscow: FSAI "Rosinformagrotech".

[8] Marakayeva TV, Nozhenko TV \& Nekrasova EV (2017), Organizatsiya sistem sevooborotov s uchetom balansa gumusa na osnove ekonomiko-matematicheskogo modelirovaniya [Organization of crop rotation systems taking into account the humus balance on the basis of economic and mathematical modeling]. Bulletin of the Altai State Agrarian University 8(154), 63-67.

[9] Dvarokovskiy MS (1983), Ekologiya rasteniy [Ecology of plants]. Moscow: Nauka.

[10] Edimeichev YuF (2004), Adaptivnyye sevooboroty - osnova ratsional'nogo zemlepol'zovaniya [Adaptive crop rotations are the basis for rational land use]. Ministry of Agriculture of the Russian Federation, Federal State Educational Institution of Higher Professional Education "Krasnoyarsk State Agrarian University". Krasnoyarsk: KrasGau.

[11] Nozhenko TV \& Marakayeva TV (2017), Landshaftnoekologicheskoye zonirovaniye $\mathrm{v}$ tselyakh ratsionalizatsii zemlepol'zovaniya [Landscaping and environmental zoning for the purpose of rationalizing land use]. Bulletin of the Altai State Agrarian University 10(156), 65-70.

[12] Kiryushin VI (2011), Teoriya adaptivno-landshaftnogo zemledeliya $i$ proyektirovaniye agrolandshaftov. [Theory of adaptive-landscape agriculture and the design of agrolandscapes.] Moscow: KolosS. 